\title{
The localization of chitin synthase in membranous vesicles (chitosomes) in Neurospora crassa
}

\author{
J. Hans Sietsma, ${ }^{1}$ Adi Beth Din, ${ }^{2}$ Vered Ziv, ${ }^{2}$ Klaas A. Sjollema ${ }^{1}$ and \\ Oded Yarden ${ }^{2}$
}

Author for correspondence: Oded Yarden. Tel: +972 89481298 . Fax: +972 89466794.

e-mail: yardeno@indycc1.agri.huji.ac.il

1 Department of Plant Biology and Groningen Biomolecular Sciences and Biotechnology Institute, University of Groningen, Biological Center, NL-9715 NN Haren, The Netherlands

2 Department of Plant Pathology and Microbiology and The Otto Warburg Center for Agricultural Biotechnology, The Faculty of Agriculture, The Hebrew University of Jerusalem, Rehovot, 76100 Israel

\begin{abstract}
Polyclonal anti-chitin synthase antibodies raised against the Saccharomyces cerevisiae CHS2 gene product were used to identify and localize chitin synthase in the filamentous ascomycete Neurospora crassa. A single band of approximately $110 \mathrm{kDa}$ was observed in Western blots of total protein extracts of $\boldsymbol{N}$. crassa, probed with these antibodies. However, several additional bands were labelled when membrane fraction proteins (microsomes) were probed. Histo-immunochemical localization of chitin synthase confirmed that the polypeptide is compartmentalized in membranous vesicles (chitosomes), which are abundant in the vicinity of the hyphal tip. TEM analysis did not reveal chitin synthase in the plasma membrane. However, dense labelling of membrane-associated chitin synthase was observed by light-microscopic analysis of $\boldsymbol{N}$. crassa protoplasts and at young hyphal tips.
\end{abstract}

Keywords: cell wall biosynthesis, hyphal growth, protoplast

\section{INTRODUCTION}

Most fungal species have several genes encoding different chitin synthases (Bulawa, 1993; Bowen et al., 1992; Mellado et al., 1995; Yanai et al., 1994; Yarden, 1993). However, very little is known about their functions.

In Saccharomyces cerevisiae, there is evidence that chitin synthase activity is regulated during the cell cycle and that products of different genes have different functions. However, an overlapping of gene product activity has not been excluded (Choi et al., 1994; Pammer et al., 1992; Shaw et al., 1991). Chitin synthase activity is found exclusively in growing regions of the fungal cell (hyphal tips and the surface of the expanding bud in yeast) and during septum formation (Sietsma \& Wessels, 1994). However, the regulation of this enzyme's activity is still unclear.

To date, there is no evidence of signal sequences for secretion (Au-Young \& Robbins, 1990; Bulawa et al., 1986; Silverman, 1989; Valdivieso et al., 1991; Yanai et al., 1994). This indicates that chitin synthase is not transported to the cytoplasmic membrane via the regular secretion pathway. However, several biochemical and cytological studies have shown the association of chitin synthesis activity with microvesicles, designated chito- somes (Bracker et al., 1976; Leal-Morales et al., 1988; Ruiz-Herrera, 1992). Based on this observation, a model was proposed suggesting that chitin synthase is transported to the growing zone of the cell in a compartmentalized form, packed in chitosomes, thereby preventing it from interacting with the sugar substrate within the cytoplasm (Bracker et al., 1976). The mechanism of chitin synthase activation upon arrival at the growing zone is still a matter of controversy: it could be activated by proteolysis (Duran et al., 1975) or by the conformational changes imposed by insertion of the polypeptide into the cytoplasmic membrane (Vermeulen \& Wessels, 1983).

In order to explain the gradient of chitin synthesis at the hyphal tip, two hypothetical mechanisms may be envisaged for the regulation of chitin synthase activity following activation. (i) The enzyme could be active for a short period of time, inactivated by a reversible mechanism and remain inactive within the cytoplasmic membrane. The enzyme could then be reactivated when needed (e.g. when new growing points are initiated, as in the case of branching and new bud formation). (ii) The enzyme could be activated for a longer period of time. Thus, the active enzyme would advance with the growing tip or expanding bud. The first mechanism would predict that 
chitin synthase is present over the entire plasma membrane, whereas in the latter case the presence of chitin synthase would be restricted to the growing zones.

The controversies concerning the movement and spatial distribution of chitin synthase could be resolved if antibodies against chitin synthase were available and in situ localization studies could be carried out. Here we show that we have an antibody preparation which is capable of recognizing chitin synthases in both $S$. cerevisiae and Neurospora crassa. This preparation reacts with chitosome-like vesicles in $N$. crassa, in particular those located in growing hyphal tips. In protoplasts, we obtained indications that chitin synthase is particularly located at putative growing zones and is not present over the entire surface.

\section{METHODS}

Strains and cultivation. Wild-type $N$. crassa strain 74-OR23-1A was used in this study. Growth and maintenance were as described by Davis \& de Serres (1970). For microscopic examination, $N$. crassa was grown between two presterilized cellophane membranes on $1.5 \%(\mathrm{w} / \mathrm{v}$ ) agar containing Vogel's minimal medium N (Vogel, 1956). Protoplasts were prepared according to standard procedures (Orbach et al., 1986) and stored at $-80^{\circ} \mathrm{C}$. S. cerevisiae, wild-type strain X2180-1A, was grown and used as previously reported (Hartland et al., 1994).

Preparation of antibody against chitin synthase. Two constructs were made for the expression of chitin synthase genes in Escherichia coli: pRIT2T/CHS2 to express CHS2 of $S$. cerevisiae, and pVZG15 to express cbs- 2 of $N$. crassa. pRIT2T/ CHS2 contains the $B g l \mathrm{II}-H i n \mathrm{dIII}$ fragment from the plasmid pSS2, harbouring the CHS2 gene from S. cerevisiae (Silverman, 1989; Silverman et al., 1988). The gene was inserted, in-frame, downstream of the phage lambda $\mathrm{P}_{\mathbf{R}}$ promoter and the coding sequence of the IgG-binding domain of Protein A (ProtA) into pRIT2T (Pharmacia). When this plasmid was transformed into $E$. coli host cells, containing the temperature-sensitive lambda cI875 repressor of the $\mathrm{P}_{\mathrm{R}}$ promoter and incubated at $37^{\circ} \mathrm{C}$, the cells did not grow. Therefore, use was made of the temperatureinducible promoter, by growing the cells at $30^{\circ} \mathrm{C}$ for $48 \mathrm{~h}$ and then transferring them to $42^{\circ} \mathrm{C}$. After $1 \mathrm{~h}$, the cells were lysed by brief ultrasonic treatment, and total protein was extracted with $0 \cdot 1 \mathrm{M}$ Tris buffer containing $2 \%$ (w/v) SDS and resolved by SDS-PAGE. A duplicate gel was blotted and the fusion protein was located using the IgG binding capacity of the ProtA attachment, by treating the blot with anti-horseradish peroxidase coupled to horseradish peroxidase (PAP). The appropriate band was excised from the untreated gel, and the protein was electro-eluted and subsequently injected into a rabbit to raise antibodies. The immune and preimmune sera were purified from antibodies against $E$. coli proteins by adsorption to a total protein extract from $E$. coli host cells not containing the plasmid. pAB225 was constructed by subcloning a $N$. crassa chs-2 EcoRV gene fragment from pAB22 (Beth Din \& Yarden, 1994) into Bluescript-SK (Stratagene). pVZ15 was prepared by cloning a $1282 \mathrm{bp} E c o \mathrm{RV}-E c o \mathrm{RI}$ fragment from pAB225 into the SmaI-EcoRI sites of Bluescript. This clone contains a fragment of $c b s-2$ which encodes amino acids 84-511 of the predicted CHS2 polypeptide. pVZ15 was digested with $B a m \mathrm{HI}-E c o \mathrm{RI}$ and the insert cloned into plasmid pGEX2 (Pharmacia), predigested with the same restriction enzymes. The resulting construct (designated pVZG15) had a fragment of chs-2 cloned in-frame (as verified by sequencing) with the glutathione- $S$-transferase-encoding gene fragment present in
pGEX2. The resulting $78 \mathrm{kDa}$ glutathione- $S$-transferase:: CHS2 fusion protein was produced in E. coli.

Protein extracts and Western blotting. Protein extracts were prepared from shaken liquid medium cultures of $N$. crassa grown overnight. The mycelium was harvested by filtration and disrupted in a bead beater (Biospec Products). $S$. cerevisiae was grown for $48 \mathrm{~h}$ in liquid culture. Cells were harvested by centrifugation and disrupted by shaking on a vortex apparatus for $1 \mathrm{~min}$ with an equal volume of glass beads $(0.5 \mathrm{~mm}$ diameter). Crude extracts were obtained by extracting homogenates with $2 \% \mathrm{SDS}$ in $1 \mathrm{M}$ Tris $/ \mathrm{HCl} \mathrm{pH} 7.5$ for $2 \mathrm{~h}$ in a boiling water bath. The suspensions were centrifuged and the supernatants loaded onto an SDS-polyacrylamide gel. The microsomal fraction of $N$. crassa was prepared by centrifuging the $3000 \mathrm{~g}$ supernatant of the disrupted mycelium at $100000 \mathrm{~g}$ for $1 \mathrm{~h}$. The pellet was extracted with $2 \% \mathrm{SDS}, 1 \mathrm{M}$ Tris/ $\mathrm{HCl}$ $\mathrm{pH} 7.5$ for $2 \mathrm{~h}$ in a boiling water bath and the extract was loaded onto an SDS-polyacrylamide gel. The gels were blotted by either electro-dry-blotting or standard electro-blotting to PVDF or nitrocellulose membranes, respectively. The blots were washed with PBS, blocked with skim-milk proteins and incubated with dilute $(1: 1000)$ antiserum or preimmune serum in $0.5 \%(\mathrm{w} / \mathrm{v})$ skim-milk proteins and PBS. The antibodies were visualized by treating with goat anti-rabbit IgG coupled to alkaline phosphatase and the colour was developed by incubation with nitroblue tetrazolium and 5-bromo-4-chloro-3indolyl phosphate (Boehringer Mannheim).

Chitin synthase assays. Mycelium was filter harvested from $250 \mathrm{ml}$ of $16 \mathrm{~h}$ shaken cultures, washed, and suspended in $25 \mathrm{ml}$ $10 \mathrm{mM}$ Tris buffer $\mathrm{pH} 7.5$ with $10 \mathrm{mM} \mathrm{MgCl}_{2}$. The mycelium was frozen in liquid nitrogen and subsequently fragmented by pressing through an X-Press (LKB). After thawing, the mixedmembrane (microsomal) fraction was isolated by centrifuging the $3000 \mathrm{~g}$ supernatant of the mycelial cell-free extract at $45000 \mathrm{~g}$ in a swing-bucket rotor for $1 \mathrm{~h}$ at $4{ }^{\circ} \mathrm{C}$ (TST 4114 rotor, Centrikon). The pellet was suspended in $2.5 \mathrm{ml} 10 \mathrm{mM}$ Tris buffer $\mathrm{pH} 7.5$ with $10 \mathrm{mM} \mathrm{MgCl}$ and stored at $-80^{\circ} \mathrm{C}$ until analysis. Chitin synthase was activated by adding $5 \mu$ trypsin $\left(0.2 \mathrm{mg} \mathrm{ml}^{-1}\right)$ to $60 \mu \mathrm{l}$ mixed membrane suspension and incubating for $15 \mathrm{~min}$ at $30^{\circ} \mathrm{C}$. Activation was stopped by adding $5 \mu \mathrm{l}$ trypsin inhibitor $\left(0.3 \mathrm{mg} \mathrm{ml}^{-1}\right)$. Diluted antibody $(5 \mu \mathrm{l})$ was added and the mixture was incubated for $1 \mathrm{~h}$ at $30^{\circ} \mathrm{C}$. Then the substrate for the chitin synthase reaction was added $[60 \mathrm{mM} \mathrm{N}$ acetylglucosamine, $6 \mathrm{mM}\left[\mathrm{U}^{14} \mathrm{C}\right] \mathrm{UDPGlcN} A \mathrm{c}, 0.08 \mathrm{mCi}(29.6$ $\mathrm{MBq}) \mathrm{mmol}^{-1}$ ] and the incubation continued for $1.5 \mathrm{~h}$ at $30^{\circ} \mathrm{C}$; the reaction was stopped by the addition of $100 \mu \mathrm{l} 1 \mathrm{M} \mathrm{NaOH}$. Insoluble material was collected on glass-fibre filter disks (Whatman $\mathrm{CF} / \mathrm{C}$ ), washed with $0.5 \mathrm{M} \mathrm{NaOH}$ followed by a mixture of $1 \mathrm{M}$ acetic acid/ethanol $(8: 2, \mathrm{v} / \mathrm{v})$ and finally with ethanol, and dried at $60^{\circ} \mathrm{C}$. The radioactivity on the filter was measured in a liquid scintillation counter.

Microscopy. Mycelium was fixed for electron microscopic analysis by placing fixative $[2.5 \%(\mathrm{v} / \mathrm{v})$ formaldehyde, $0.5 \%$ glutaraldehyde in $0.05 \mathrm{M}$ phosphate buffer $\mathrm{pH} 7.2$ ] on the top membrane while the mycelium was still on the agar plate between two cellophane membranes. After $2 \mathrm{~h}$ at room temperature, the top membrane was removed and the mycelium embedded in a thin layer of $1.5 \%(w / v)$ agar solution. After solidification of the agar small blocks containing most of the hyphal tips were cut from the edge of the colony, dehydrated in a series of $50-100 \%$ ethanol washes and incubated overnight in Unicryl. The agar blocks were placed in flat-bottomed TAAB capsules filled with fresh Unicryl and polymerized for $3 \mathrm{~d}$ under UV light at $4^{\circ} \mathrm{C}$. Ultra-thin sections were cut in an LKB microtome and placed on Formvar/carbon-coated nickel, single-hole grids. Sections were negatively stained with $1 \%$ 
(w/v) uranyl acetate. For immunolabelling, each grid was incubated for $5 \mathrm{~min}$ with a drop of $0.5 \% \mathrm{BSA}$ in PBS and subsequently with a $10^{-3}$ dilution of anti-serum in $0.5 \% \mathrm{BSA}$ in PBS, washed with PBS and treated with $15 \mathrm{~nm}$ gold-labelled goat anti-rabbit IgG (Sigma) and visualized with a Philips CM 10.

For light microscopic analysis, protoplasts were washed with $0.05 \mathrm{M}$ phosphate buffer $\mathrm{pH} 7.2$ supplemented with $0.5 \mathrm{M}$ sorbitol as an osmotic stabilizer and fixed in the same solution with $2.5 \%$ formaldehyde and $0.5 \%$ glutaraldehyde for $2 \mathrm{~h}$ at room temperature. The fixative was removed by washing with water and PBS, and the fixed protoplasts were resuspended in PBS with $0.5 \% \mathrm{BSA}$ as blocking agent and incubated for $1 \mathrm{~h}$ at room temperature. The liquid was removed and the protoplasts were suspended in the same solution containing 1000-fold diluted antiserum. Incubation was continued overnight with gentle shaking. Antiserum was removed by washing with PBS and the protoplasts were subsequently treated for $2 \mathrm{~h}$ at room temperature with $15 \mathrm{~nm}$ gold-labelled goat anti-rabbit IgG. The gold particles were visualized with a silver enhancing kit (Biocell) and viewed with a Zeiss Axioscope. As a control, the fixed protoplasts were treated with preimmune serum by the same procedure.

\section{RESULTS}

\section{Specificity of the antibody preparation}

Antibodies were raised against a protein obtained by expressing, in E. coli, a plasmid containing a fusion of the ProtA gene with CHS2 from S. cerevisiae. The fusion protein was identified as a band reacting with $\operatorname{IgG}$ (indicating the presence of $\operatorname{Prot} A$ ) and showing the expected size. The antiserum raised was purified by successive incubations with total protein extract from $E$.

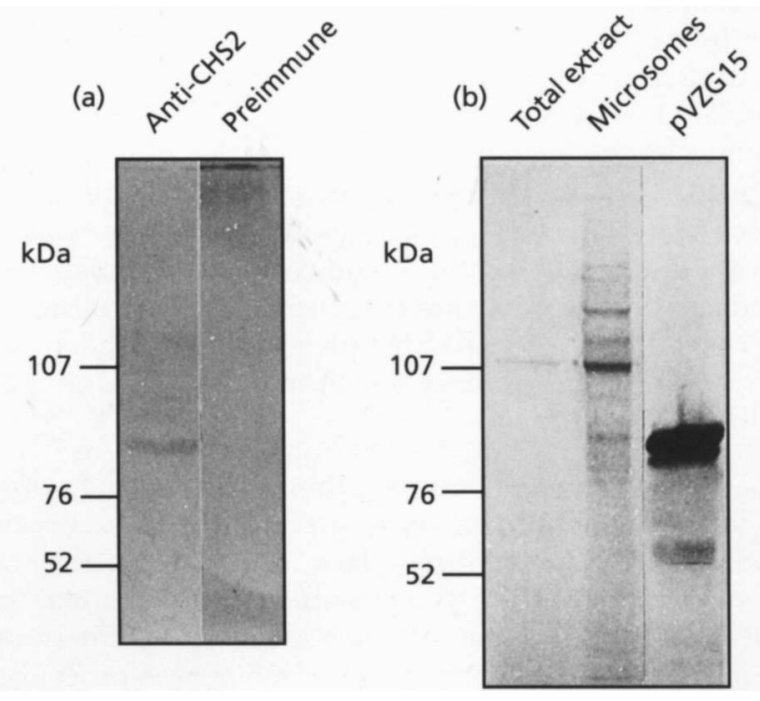

Fig. 1. Western blot analysis of protein extracts from (a) $S$. cerevisiae probed with anti-CHS2 antibodies and preimmune antiserum, and (b) $N$. crassa probed with anti-CHS2 antibodies (total protein extract, protein extracted from the microsomal fraction and protein extracted from $E$. coli carrying pVZG15 and overproducing part of the $N$. crassa chs-2 gene product are shown). The positions of molecular mass markers are indicated on the left.
Table 1. Effect of anti-chitin synthase antibodies on in vitro chitin synthase activity in extracts from $N$. crassa

The results are means of five determinations, \pm SE.

\begin{tabular}{|lcc|}
\hline $\begin{array}{l}\text { Antibody } \\
\text { dilution }\end{array}$ & $\begin{array}{c}\text { Incorporation of }\left[{ }^{14} \mathrm{C}\right] \text { UDPGlcNAc into } \\
\text { insoluble material (\%) }\end{array}$ \\
\cline { 2 - 3 } & Immune & Preimmune \\
\hline No antibodies & 100 & 100 \\
$10^{-5}$ & $95 \cdot 2 \pm 0 \cdot 3$ & $98 \cdot 5 \pm 0.5$ \\
$5 \times 10^{-4}$ & $78 \cdot 5 \pm 0 \cdot 5$ & $96 \cdot 8 \pm 0 \cdot 2$ \\
$10^{-4}$ & $67 \cdot 6 \pm 0 \cdot 3$ & $96 \cdot 1 \pm 0 \cdot 6$ \\
$10^{-3}$ & $47 \cdot 1 \pm 0 \cdot 3$ & $94 \cdot 3 \pm 0 \cdot 4$ \\
\hline
\end{tabular}

coli adsorbed to a PVDF membrane until a Western blot of $E$. coli proteins did not react with the antibody preparation. The preimmune serum was treated similarly.

The purified antiserum reacted with several protein bands of approximately $90 \mathrm{kDa}$, on a Western blot of total $S$. cerevisiae proteins (Fig. 1a). No bands were visible when identical blots were probed with the preimmune serum (Fig. 1a, right lane). In order to determine the reactivity of the purified antibody preparation with other fungal chitin synthases, a Western blot of $N$. crassa extracts was probed with the antibody. The anti $S$. cerevisiae $\mathrm{CHS} 2$ polyclonal antibodies reacted with at least one $N$. crassa chitin synthase present in total protein extracts (Fig. 1b). The antibody probably also reacted with additional, less abundant, chitin synthases, because several reacting bands were visible in the $N$. crassa microsomal preparation. It reacted very strongly with a fusion protein obtained when pVZG15, the plasmid containing part of the chs-2 gene from $N$. crassa, was overexpressed in E. coli. This was not unexpected, as the predicted amino acid sequence of the overexpressed $N$. crassa gene product is highly similar to that of the yeast CHS2 polypeptide. Nonetheless, we cannot conclude, on the basis of the reactivity of the antibodies with the $N$. crassa CHS2 fusion protein, that the single band evident in the $N$. crassa extract is in fact CHS2. It could well be that the observed band represents a different, more abundant, chitin synthase. The chitin synthase activity measured in the mixed membrane preparation of $N$. crassa was significantly inhibited by addition of the immune serum. The level of inhibition was positively correlated with the amount of antibody added to the reaction mixture. No significant reduction in chitin synthase activity was observed in control reactions amended with the preimmune serum (Table 1). The specificity observed in the immunoblotting and chitin synthase activity assays suggests that the antibody preparation recognizes general epitopes present on different chitin synthases even from different fungal species.

\section{Histo-immunochemical localization of chitin synthase}

Transmission electron and light microscopy were used to localize chitin synthase in situ. When probed with the gold-conjugated antibodies, distinct and specific labelling 

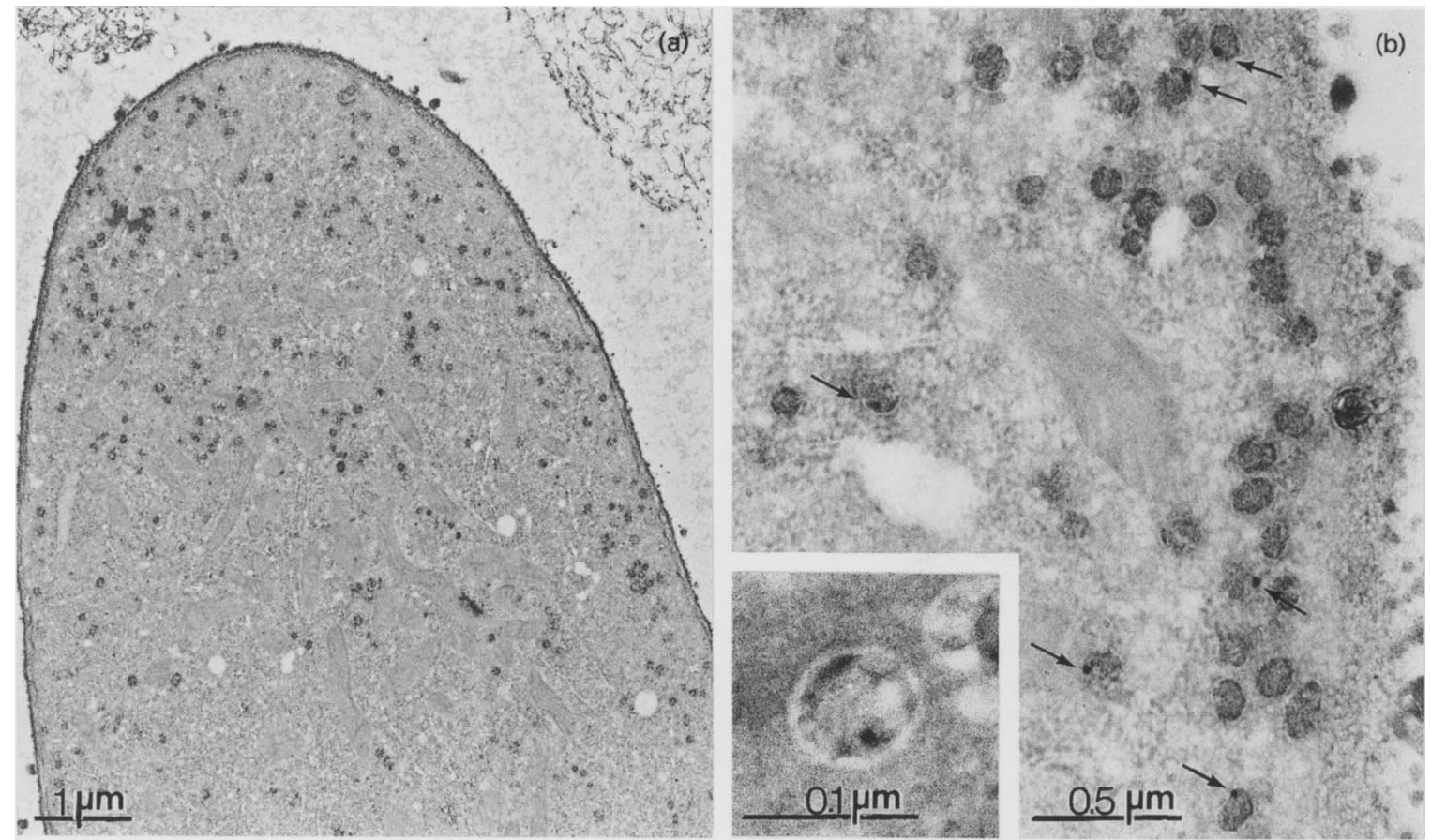

Fig. 2. TEM analysis of $N$. crassa hyphae labelled with anti-chitin synthase antibodies followed by secondary labelling with colloidal gold-goat anti-rabbit antibodies. Arrows point to gold label appearing as black spheres, $15 \mathrm{~nm}$ in diameter. (a) Cross-section through $N$. crassa hypha near the tip region (note the increasing concentration of vesicles towards the tip). (b) Enlargement of a cluster of vesicles showing the partial labelling. The inset shows an enlargement of a vesicle with the gold particles clearly associated with the inside of the periphery. The white halo around the vesicle with black dots is interpreted as evidence for a membrane vesicle with inserted protein molecules.

of chitin synthase in hyphae of $N$. crassa was observed (Fig. 2). The label was located near the hyphal tips (Fig. 2a) and was associated with membrane-like coated vesicles (Fig. 2b), although under higher magnification only approximately $10 \%$ of the vesicles appeared to be labelled (Fig. 2b). The high relative abundance of vesicles at the hyphal tip has been well documented (Collinge \& Trinci, 1974; Bartnicki-Garcia et al., 1978; Ruiz-Herrera, 1992). The labelled vesicles measured approximately $40-80 \mathrm{~nm}$ in diameter. Higher magnification (inset of Fig. 2b) indicated that they are surrounded by a membrane-like envelope containing several spots that stain like protein molecules of which only a few carried label. It is worth noting that when a vesicle was labelled, the label seemed to be predominantly located inside the vesicle and associated with the periphery. The size, optical characteristics and spatial distribution of the vesicles were in full agreement with those of the vesicles (designated chitosomes) which have been previously described as being vehicles of chitin synthase within the cell (Bracker et al., 1976; Leal-Morales et al., 1988; Bartnicki-Garcia et al., 1978).

An unexpected finding was the lack of any marked abundance of label along the cell membrane. Because chitin synthase activity is associated with the membranous fraction of the cell, we assumed that chitin synthase deposited along the cell membrane would be detected with the antibody preparation. There are several possible explanations for the lack of detectable signal along the membrane: (i) the polypeptide is either very sparsely distributed or a high turnover rate of plasma-membraneassociated enzyme results in a low abundance of the enzyme in the membrane; (ii) once the polypeptide is embedded in the membrane, proteolysis or other processes which may impose changes in protein conformation or additional alterations, could modify polypeptide epitopes to the extent that they are no longer recognized by the antibodies; (iii) the presence of the cell wall imposes steric interference which spatially limits antigenantibody interactions.

To address some of these possibilities, we carried out in situ immunostaining of $N$. crassa protoplasts. Because protoplasts almost entirely lack a cell wall, they are convenient for testing the possible effects an intact cell wall may have on the labelling process. Furthermore, because the cell wall biosynthetic machinery in protoplasts is highly active, it is conceivable that elevated levels of chitin synthase may be required. The relatively high enzyme levels would assist in the localization procedure. Protoplasts were fixed in the presence of an osmotic stabilizer and treated with the antiserum against chitin synthase. Antibody localization was made possible via silver enhancement of the $15 \mathrm{~nm}$ gold-labelled goat antirabbit IgG secondary antibody. Approximately $25 \%$ of 


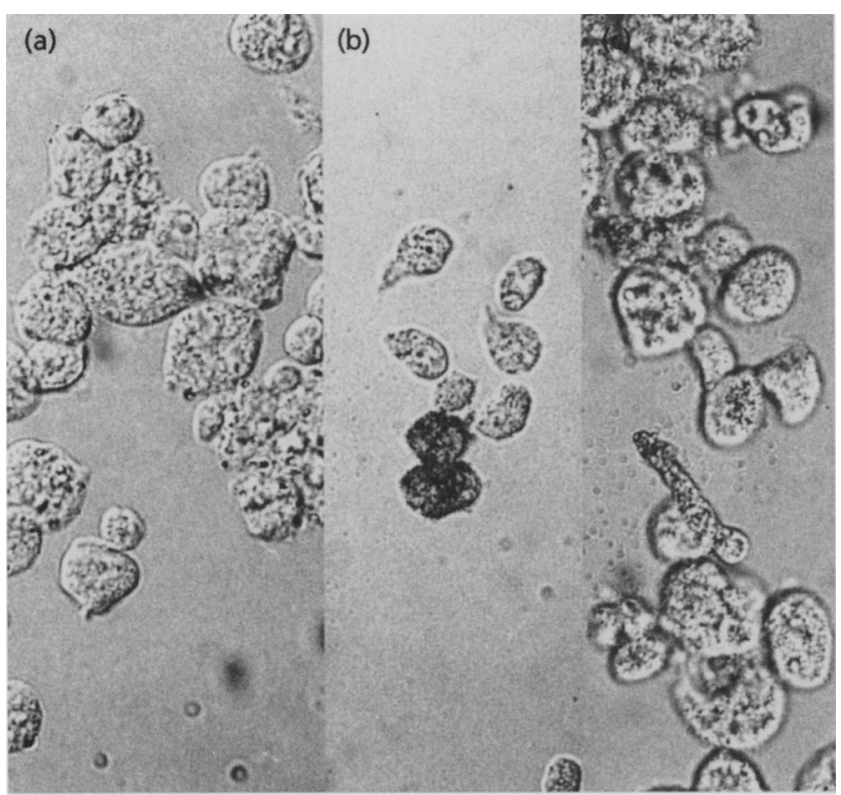

Fig. 3. Chitin synthase localization in $N$. crassa protoplasts. Fixed protoplasts were labelled and viewed with a light microscope following silver enhancement of colloidal goldlabelled secondary antibody. (a) Protoplasts labelled with preimmune serum. (b, c) Protoplasts labelled with anti-chitin synthase antibody. Note that not all the protoplasts are labelled and that protoplasts vary with regard to label localization and intensity. A high occurrence of label along the protoplast membrane can be observed. A germinating conidium is heavily labelled, with the highest label intensity at the growing hyphal tip.

the protoplasts were labelled (Fig. 3). A small percentage was labelled over the entire surface whereas the majority of the protoplasts were found to be labelled in confined regions of the cell - in most cases along the plasma membrane. The non-uniform labelling could be attributable to several factors (e.g. phases in protoplast regeneration, protoplast viability, uniformity of protoplast/antibody dispersal during the labelling procedure). Because protoplast mixtures are rarely uniform, developing a finer, more synchronous protoplast preparation may prove useful in future in situ analyses.

\section{DISCUSSION}

We prepared and used anti-chitin synthase polyclonal antibodies to identify and localize the polypeptide in the filamentous fungal cell. Our results indicate that in addition to a single reacting polypeptide of approximately $110 \mathrm{kDa}$ observed in the unfractionated $N$. crassa cell-free extract, several additional bands which may represent other, less abundant chitin synthases react with the purified antibody preparation. However, this interpretation should be approached with caution, as it is also possible that antibodies against the presumed membraneanchoring region in the chitin synthase polypeptide can identify similar domains in other, unrelated proteins. Bracker et al. (1976) suggested that chitin synthase is conveyed to the cell surface in cytoplasmic containers termed chitosomes. Our results confirm the presence of chitin synthase in vesicles which fit the characteristics of chitosomes (between 50 and $100 \mathrm{~nm}$ in diameter and enclosed within a membrane; Bracker et al., 1976) which were found mainly in the vicinity of the hyphal tip. Nonetheless, only about $10 \%$ of the vesicles were labelled. Several possibilities could explain this observation. (i) Different vesicles could contain different chitin synthases, some of which are not identified by the antibodies, e.g. complex-type chitin synthases like the yeast CSD2 (Bulawa, 1992) or the N. crassa CHS4 (Beth Din et al., 1996) enzymes, which have a lower degree of amino acid sequence similarity to the polypeptide used to raise the antibodies. (ii) Some of the vesicles may not contain any chitin synthase at all. Because chitin synthase is not the only protein deposited at the hyphal tip, other enzymes, e.g. glucan synthase, could be trafficked in a similar way. (iii) The sections cut for electron microscopy were approximately $75-100 \mathrm{~nm}$ thick, which is close to the diameter of the vesicles. Thus, it is likely that a considerable number of vesicles were not sectioned in such a way that the antibody could contact the vesicle-enclosed epitope.

The fact that not all protoplasts were labelled may be linked to the specific protoplast regeneration phase, in which some protoplasts were not able to regenerate while in others chitin synthesis occurs either over the entire cell surface or at limited foci. Studies of protoplast regeneration in Schizopbyllum commune have shown that during the first stages of regeneration, chitin synthesis occurs over the entire surface of the protoplast; at later stages, when orientation to the hyphal form occurs, chitin synthesis is restricted to the growing points (van der Valk $\&$ Wessels, 1976). The present study indicates that a small percentage of the labelled protoplasts show label over the entire surface and the remainder are labelled only in certain regions. One could hypothesize that the former population represents protoplasts at an early stage of regeneration and the latter represents protoplasts during a later stage, namely the reversion to the hyphal form. These results suggest that we can, in fact, detect chitin synthase on the membrane, but the enzyme is present in the membrane only at very distinct time periods of fungal growth. Nonetheless, it appears that the presence of the cell wall may affect the accessibility of the plasma membrane-associated chitin synthases to the antibodies.

Our results suggest a correlation between chitin synthase activity and chitin synthase polypeptide localization, but no indication of the general presence of chitin synthase in the cytoplasmic membrane of the full-grown cell.

Machida et al. (1994) used immuno-electron microscopy to study chitin synthase in Absidia glauca. In their study, a chitin synthase of approximately $30 \mathrm{kDa}$ was found (which is significantly smaller than most of the chitin synthase polypeptide masses predicted on the basis of genetic and biochemical data) which was present along the borders of relatively large (several hundred nanometres in diameter) vacuoles and along the plasma membrane. Although studies by Bartnicki-Garcia et al. (1978) have clearly demonstrated the localization of chitin 
synthase to chitosomes in Zygomycetous species, it is possible that in $A$. glauca, chitin synthase is localized differently. Further analysis of chitin synthase in additional fungal species should reveal whether such differences exist.

\section{ACKNOWLEDGEMENTS}

This research was supported, in part, by the Wolfson Research Awards administered by the Israel Academy of Sciences and Humanities. The construction of pRIT2T/CHS2 was performed during a sabbatical leave of J.H. S. in Dr Enrico Cabib's laboratory at the NIH, Bethesda, MD, USA. The help, suggestions and discussions of Drs Enrico Cabib, Sandy Silverman and Andy Shaw are very much appreciated. We thank Professor Joseph Wessels for critically reading the manuscript. The technical assistance of Ella Haber is very much appreciated.

\section{REFERENCES}

Au-Young, J. \& Robbins, P. W. (1990). Isolation of a chitin synthase gene (CHS1) from Candida albicans by expression in Saccharomyces cerevisiae. Mol Microbiol 4, 197-207.

Bartnicki-Garcia, S., Bracker, C. E., Reyes, E. \& Ruiz-Herrera, J. (1978). Isolation of chitosomes from taxonomically diverse fungi and synthesis of chitin microfibrils in vitro. Exp Mycol 2, 173-192.

Beth Din, A. \& Yarden, O. (1994). The Neurospora crassa chs-2 gene encodes a non-essential chitin synthase. Microbiology 140, 2189-2197.

Beth Din, A., Specht, C. A., Robbins, P. W. \& Yarden, O. (1996). $c b s-4$, a class IV chitin synthase gene from Neurospora crassa. Mol Gen Genet 250, 214-222.

Bowen, A. R., Chen-Wu, J. L., Momany, M., Young, R., Szaniszlo, P. J. \& Robbins, P. W. (1992). Classification of fungal chitin synthases. Proc Natl Acad Sci US A 89, 519-523.

Bracker, C. E., Ruiz-Herrera, J. \& Bartnicki-Garcia, S. (1976). Structure and transformation of chitin synthetase particles (chitosomes) during microfibril synthesis in vitro. Proc Natl Acad Sci US A 73, 4570-4574.

Bulawa, C. E. (1992). CSD2, CSD3, and CSD4, genes required for chitin synthesis in yeast: the CSD2 gene product is related to chitin synthases and to developmentally regulated proteins in Rhizobium and Xenopus. Mol Cell Biol 12, 1764-1776.

Bulawa, C. E. (1993). Genetics and molecular biology of chitin synthesis in fungi. Ann Rev Microbiol 47, 505-534.

Bulawa, C. E., Slater, M., Cabib, E., Au-Young, J., Sburlati, A., Adair, W. L. J. \& Robbins, P. W. (1986). The $S$. cerevisiae structural gene for chitin synthase is not required for chitin synthesis in vivo. Cell 46, 213-225.

Choi, W. J., Santos, B., Duran, A. \& Cabib, E. (1994). Are yeast chitin synthases regulated at the transcriptional or the posttranslational level? Mol Cell Biol 14, 7685-7694.

Collinge, A. J. \& Trinci, A. P. J. (1974). Hyphal tips of wild-type and spreading colonial mutants of Neurospora crassa. Arch Microbiol 99, 353-368.

Davis, R. H. \& de Serres, F. J. (1970). Genetic and microbiological research techniques for Neurospora crassa. Methods Enzymol 17A, 79-143.

Duran, A., Bowers, B. \& Cabib, E. (1975). Chitin synthetase zymogen is attached to the yeast plasma membrane. Proc Natl Acad Sci US A 73, 3952-3955.

Hartland, R. P., Vermeulen, C. A., Klis, F. M., Sietsma, J. H. \& Wessels, J. G. H. (1994). The linkage of $(1 \rightarrow 3)$-beta-glucan to chitin during cell wall assembly in Schizopbyllum commune. Yeast 10, 1591-1599.

Leal-Morales, C. A., Bracker, C. E. \& Bartnicki-Garcia, S. (1988). Localization of chitin synthetase in cell-free homogenates of Saccharomyces cerevisiae: chitosomes and plasma membrane. Proc Natl Acad Sci USA 85, 8516-8520.

Machida, S., Itoh, Y., Kishida, H., Higasa, T. \& Saito, M. (1994). Localization of chitin synthase in Absidia glauca studied by immunoelectron microscopy: application of cryoultramicrotomy. Biosci Biotechnol Biochem 58, 1983-1989.

Mellado, E., Aufauvre-Brown, C., Specht, C. A., Robbins, P. W. \& Holden, D. W. (1995). A multigene family related to chitin synthase genes of yeast in the opportunistic pathogen Aspergillus fumigatus. Mol Gen Genet 246, 353-359.

Orbach, M. J., Porro, E. B. \& Yanofsky, C. (1986). Cloning and characterization of the gene for $\beta$-tubulin from a benomyl-resistant mutant of Neurospora crassa and its use as a dominant selectable marker. Mol Cell Biol 6, 2452-2461.

Pammer, M., Briza, P., Ellinger, A., Schuster, T., Stucka, R., Fedelmann, H. \& Breitenbach, M. (1992). DIT101 (CSD2, CALI), a cell cycle-regulated yeast gene required for chitin in cell walls and chitosan in spore walls. Yeast 8, 1089-1099.

Ruiz-Herrera, J. (1992). Fungal Cell Wall: Structure, Synthesis and Assembly. Boca Raton: CRC Press.

Shaw, J. A., Mol, P. C., Bowers, B., Silverman, S. J., Valdivieso, M. H., Duran, A. \& Cabib, E. (1991). The function of chitin synthases 2 and 3 in the Saccbaromyces cerevisiae cell cycle. J Cell Biol 114, 111-123.

Sietsma, J. H. \& Wessels, J. G. H. (1994). Apical wall biosynthesis. In The Mycota, vol. 1, pp. 125-141. Edited by J. G. H. Wessels \& F. Meinhardt. Berlin: Springer Verlag.

Silverman, S. J. (1989). Similar and different domains of chitin synthase 1 and 2 of $S$. cerevisiae isozymes with distinct function. Yeast 5, 459-467.

Silverman, S. J., Sburlati, A., Slater, M. L. \& Cabib, E. (1988). Chitin synthase 2 is essential for septum formation and cell division in Saccharomyces cerevisiae. Proc Natl Acad Sci US A 85, 4735-4739.

Valdivieso, M. H., Mol, P. C., Shaw, J. A., Cabib, E. \& Duran, A. (1991). $C A L 1$, a gene required for activity of chitin synthase 3 in Saccharomyces cerevisiae. J Cell Biol 114, 101-109.

van der Valk, P. \& Wessels, J. G. H. (1976). Ultrastructure and localization of wall polymers during regeneration and reversion of protoplasts of Scbyzophyllum commune. Protoplasma 90, 65-87.

Vermeulen, C. A. \& Wessels, J. G. H. (1983). Evidence for a phospholipid requirement of chitin synthase in Scbyzopbyllum commune. Curr Microbiol 8, 67-71.

Vogel, H. J. (1956). A convenient growth medium for Neurospora crassa (medium N). Microb Genet Bull 13, 42-43.

Yanai, K., Kojima, N., Takaya, N., Horiuchi, H., Ohta, A. \& Takagi, M. (1994). Isolation and characterization of two chitin synthase genes from Aspergillus nidulans. Biosci Biotechnol Biochem 58, 1828-1835.

Yarden, O. (1993). The chitin synthase gene family of Neurospora crassa. In Chitin Enzymology, pp. 1-6. Edited by R. A. A. Muzzarelli. Ancona: European Chitin Society.

Received 27 November 1995; revised 1 February 1996; accepted 21 February 1996. 